\title{
ANALITIČKA, EKSPERIMENTALNA I NUMERIČKA ANALIZA ČISTOG SAVIJANJA ALUMINIJSKIH NOSAČA S UMJETNO PROIZVEDENOM STRUKTUROM
}

\section{ANALYTICAL, EXPERIMENTAL AND NUMERICAL ANALYSIS OF PURE BENDING OF ALUMINUM BEAMS WITH ARTIFICIALLY PRODUCED STRUCTURE}

\section{Damjan Jurković*, Laura Žiković́, Edita Papa Dukić ${ }^{*}$, Gordan Jelenić ${ }^{*}$}

\begin{abstract}
Sažetak
Ovaj rad razmatra deformacije pri čistom savijanju homogenih i heterogenih nosača. Deformacije su određene analitičkim putem, eksperimentalno, metodom tenzometrije te metodom konačnih elemenata. Definirana je geometrija uzoraka koja čini nosače heterogenima i izvedena formula momenta površine drugog reda oslabljenog nosača. Cilj rada je provjera primjenjivosti gredne teorije za analizu heterogenih izotropnih $i$ ortotropnih nosača. Uspoređeni su rezultati tri pristupa, pri čemu su eksperimentalni rezultati korišteni kao referentni.
\end{abstract}

Ključne riječi: čisto savijanje, moment površine drugog reda, gredna teorija, metoda tenzometrije, nosači heterogene strukture, metoda konačnih elemenata

\begin{abstract}
This paper considers strains in pure bending of homogeneous and heterogeneous beams. The strains are determined analytically, experimentally, by the strain-gauge method, and numerically, by using the finite element method. The geometry of the specimens that gives the beams heterogeneous structure has been defined and the
\end{abstract}

\footnotetext{
* Sveučilište u Rijeci, Građevinski fakultet, Radmile Matejčić 3, 51000 Rijeka E-mail: djurkovic@student.uniri.hr, laura.zikovic@uniri.hr, edita.papa@uniri.hr, gordan.jelenic@uniri.hr
} 
expression for the second moment of area derived. The aim of this paper is to test the applicability of the beam theory to the analysis of heterogeneous isotropic and orthotropic structures. The results of the three approaches are compared using the experimental results as a reference set of data.

Keywords: Pure bending, second moment of area, beam theory, strain-gauge measurement, heterogeneous beams

\section{Uvod}

Gredna teorija je dominantna teorija u analiziranju homogenih izotropnih nosača, no njena uporabljivost za nosače koji nisu takvi jest upitna. Posebno je to izraženo kod materijala koji imaju određenu strukturu, gdje su uočena određena odstupanja u odnosu na eksperimentalna ispitivanja [1]. Kako bi se ispitala uporabivost gredne teorije, nosači homogene strukture, opisane u sljedećem poglavlju, u laboratoriju su opterećeni čistim savijanjem kao najjednostavnijim opterećenjem uz sudjelovanje momenta. Metodom tenzometrije izmjerene su deformacije u točkama koje su karakteristične za strukturu nosača te su te vrijednosti uzete kao referentne. Analitičkim putem proračunat je moment tromosti za nosače na kojima je to bilo primjenjivo i proračunate su očekivane deformacije. Uz to za isti problem provedena je analiza metodom konačnih elemenata (engl. Finite-Element Method, skraćeno FEM). Tijekom svake analize raspravljena su zapažanja koja su se pojavljivala u postupku. Na kraju glavnog dijela uspoređeni su rezultati za isti sustav, dobiveni pomoću tri različite metode te su izvučeni zaključci iz njihova odnosa. Cilj ovoga rada je pridonošenje razumijevanju mogućnosti uporabe gredne teorije te analiza svojstava heterogenosti nosača predstavljena u radu A.J. Beveridgea, M.A. Wheela i D.H. Nasha [2].

\section{Definiranje heterogenosti nosača i opis problema}

U ovome radu, heterogeni nosači su oni nosači čija savojna krutost $E I_{y}$ nije konstantna duž osi nosača, što se manifestira promjenom oblika ili dimenzija poprečnog presjeka. Analiziran je slučaj aluminijskih heterogenih nosača, perforiranih pravilnim rasporedom u svojoj ravnini savijanja. Laboratorijskim ispitivanjem utvrđeno je kako je Youngov modul elastičnosti materijala $\mathrm{E}=66,86 \mathrm{GPa}$. Geometrija analiziranih nosača preuzeta je iz znanstvenog rada The Micropolar Elastic Behaviour of Model Macroscopically Heterogeneous Materials autora A.J. Beveridgea, M.A. Wheela, D.H. Nasha [2]. Analizirane su dvije različite geometrije oslabljenja, koje se razlikuju u koncentraciji oslabljenja. Prema vrsti geometrije, uzorci su nazvani HMD (High mass density, eng. visoka gustoća) i LMD (low mass density, eng. niska 
gustoća). Geometrija oslabljenja definirana je pravokutnikom koji dijeli težište $s$ težištem površine kruga oslabljenja radijusa r. Pravokutnik ima širinu $\mathrm{P}_{1}$ te visinu $\mathrm{P}_{2}$. Veličine geometrije oslabljenja za strukture HMD i LMD prikazane su u Tablici 1. Na Slici 1 prikazana je heterogena struktura nosača iz koje je vidljivo da su širina $\mathrm{P}_{1}$ i visina $\mathrm{P}_{2}$ jednake horizontalnoj, odnosno vertikalnoj udaljenosti središta dva oslabljenja. Kao kontrolni uzorci korišteni su neperforirani homogeni nosači, analogno nazvani FM (Full mass, eng. puna masa). Također, analizirane su dvije različite veličine nosača koje su nazvane B2 i B3, a čije su karakteristike date u Tablici 2. Nosači B2 imaju dva reda oslabljenja, što ih čini nesimetričnim u odnosu na longitudinalnu os, dok nosači B3 imaju tri reda oslabljenja te su simetrični. Samim time, u nedeformiranom stanju neutralna os nosača B2 nije ravna linija, što je slučaj kod nosača B3, već je krivulja. Stoga na uzorke veličine B2 nije moguće primijeniti grednu teoriju te oni nisu analitički analizirani. Nosači HMD B2, LMD B2, HMD B3 i LMD B3 prikazani su na Slikama 2 i 3.

Tablica 1. Geometrija oslabljenja nosača

\begin{tabular}{|c|c|c|c|}
\hline Razina oslabljenja & $r(\mathrm{~mm})$ & $\mathrm{P}_{1}(\mathrm{~mm})$ & $\mathrm{P}_{2}(\mathrm{~mm})$ \\
\hline HMD & 3,5 & 16 & 12,7 \\
\hline LMD & 3,5 & 9 & 12,7 \\
\hline
\end{tabular}

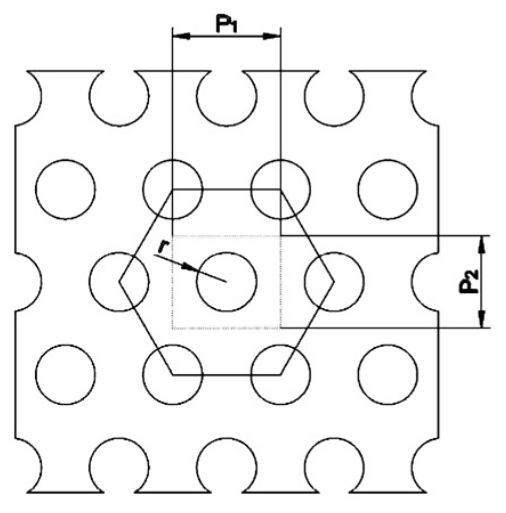

Slika 1. Struktura heterogenih nosača

Tablica 2. Geometrija nosača B2 i B3

\begin{tabular}{|c|c|c|c|}
\hline Nosač & $\begin{array}{c}\text { Visina presjeka } h \\
(\mathrm{~mm})\end{array}$ & $\begin{array}{c}\text { Širina presjeka } b \\
(\mathrm{~mm})\end{array}$ & $\begin{array}{c}\text { Duljina presjeka } l \\
(\mathrm{~mm})\end{array}$ \\
\hline B2 & 25,4 & 12,7 & 280 \\
\hline B3 & 38,1 & 12,7 & 400 \\
\hline
\end{tabular}




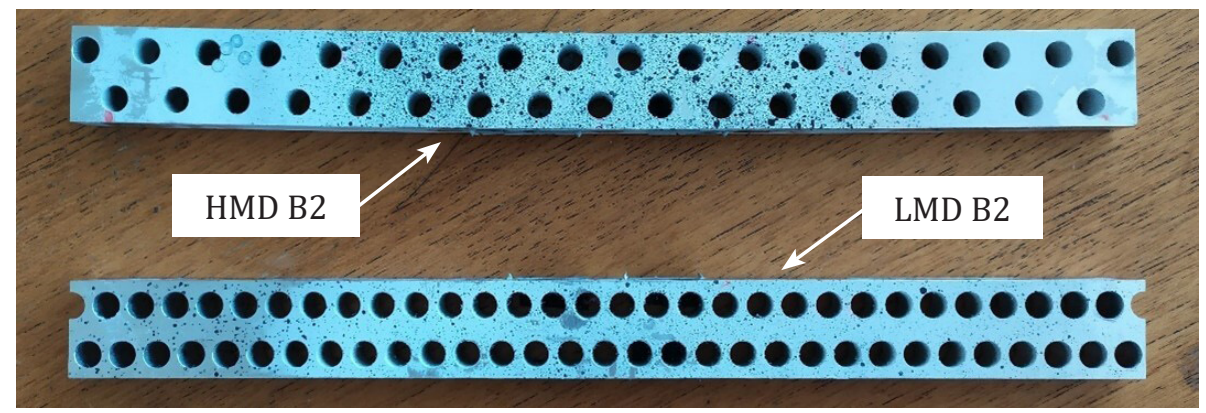

Slika 2. Ispitni uzorci HMD B2 i LMD B2 nakon ispitivanja

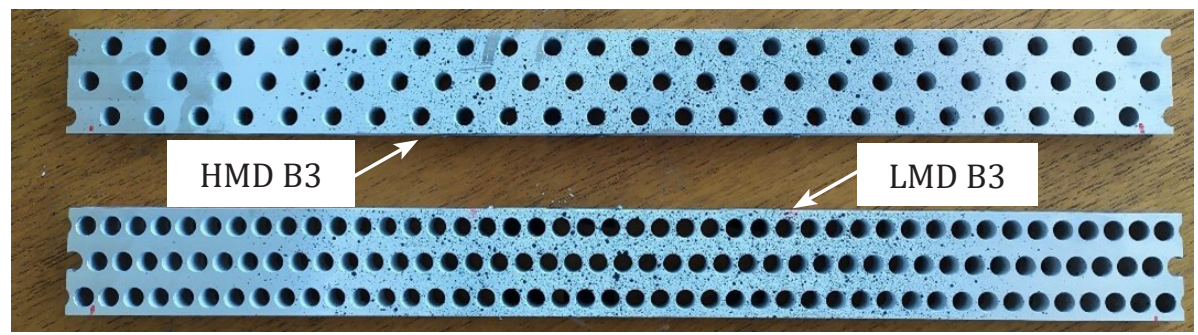

Slika 3. Ispitni uzorci HMD B3 i LMD B3 nakon ispitivanja

Nosači su opterećeni u četiri točke pomoću dva oslonca i dvije vertikalne sile između kojih se nalazi zona čistog savijanja. Ta zona je ovdje razmatrana radi konstantnog momenta duž osi nosača, a koji se pojavljuje unutar nje. Na Slici 4 prikazan je način oslanjanja i opterećenja nosača, a u Tablici 3 date su geometrijske vrijednosti sa Slike 4. Ovaj problem analiziran je analitički, eksperimentalno i numerički, kao što je prikazano u nastavku.

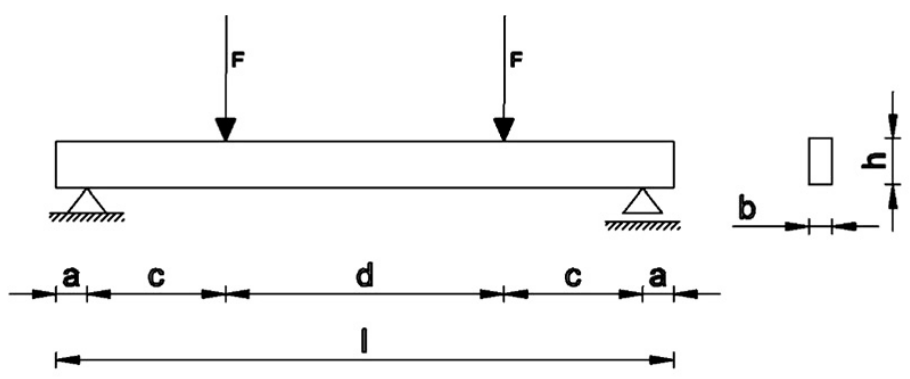

Slika 4. Geometrija nanašanja opterećenja na nosač 
Tablica 3. Geometrija opterećenog nosača

\begin{tabular}{|c|c|c|c|c|c|c|}
\hline Uzorak & $l(\mathrm{~mm})$ & $d(\mathrm{~mm})$ & $h(\mathrm{~mm})$ & $\mathrm{b}(\mathrm{mm})$ & $\mathrm{a}(\mathrm{mm})$ & $\mathrm{c}(\mathrm{mm})$ \\
\cline { 1 - 5 } B2 & 280 & 128 & 25,4 & \multirow{2}{*}{12,7} & 10 & 6 \\
\cline { 1 - 4 } B3 & 400 & 248 & 38,1 & & & \\
\hline
\end{tabular}

\section{Analitičko rješenje}

Analiza prema grednoj teoriji primijenjena je samo na nosače HMD B3 i LMD B3. Neutralna os nosača HMD B2 i LMD B2 nije pravac, već krivulja te zbog toga ne možemo primijeniti grednu teoriju za njihovu analizu.

U zoni čistog savijanja (dimenzija d na Slici 4) odabrana su dva presjeka, presjek 1 - 1, koji prolazi središtem jedne kružnice oslabljenja (jači presjek) i presjek $2-2$, koji prolazi središtem dviju kružnica (slabiji presjek), a koji su prikazani na Slici 5.

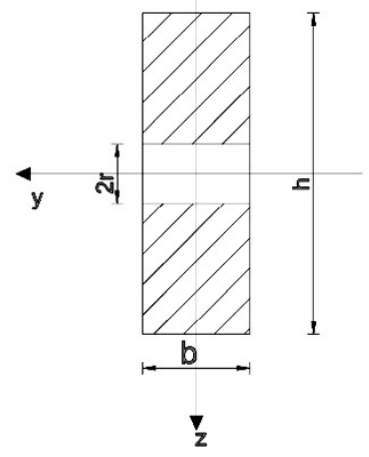

a)

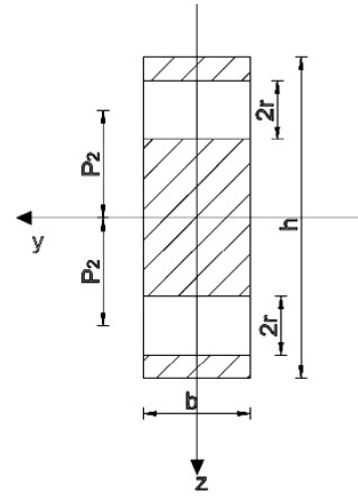

b)

Slika 5. Poprečni presjeci nosača B3: a) presjek 1 - 1 b) presjek 2 - 2

Presjek 1 - 1 sastoji se od dvije površine dimenzija $b *\left(\frac{\mathrm{h}}{2}-r\right)$, od kojih niti jedna nema težište u težištu presjeka. Primjenom Steinerovog teorema, oduzimanjem momenta površine drugog reda oslabljenja od momenta površine drugog reda punog pravokutnog presjeka dimenzija $b * h$ [3] dobivamo moment površine drugog reda presjeka 1 - 1

$$
I_{y, 1-1}=\frac{b}{12}\left(h^{3}-8 r^{3}\right)
$$

te moment otpora:

$$
W_{y, 1-1}=\frac{b}{h} \frac{\left(h^{3}-8 r^{3}\right)}{6}
$$


Uvrštavanjem dimenzija iz Tablica 1 i 2 u izraze (1) i (2) dobivamo njihove numeričke vrijednosti:

$$
\begin{gathered}
I_{y, 1-1}=58169,54 \mathrm{~mm}^{4} \\
W_{y, 1-1}=3053,52 \mathrm{~mm}^{3}
\end{gathered}
$$

Presjek 2 - 2 sastoji se od tri površine, od kojih srednja dimenzija $b *\left(2 * P_{2}-2 r\right)$ ima težište u težištu presjeka, a dvije krajnje površine dimenzija $b *\left(\frac{\mathrm{h}}{2}-P_{2}-r\right)$ nemaju težište u težištu presjeka. Primjenom Steinerovog teorema, oduzimanjem momenta površine drugog reda oslabljenja od momenta površine drugog reda punog pravokutnog presjeka dimenzija $b * h$ [3] dobivamo moment površine drugog reda presjeka 2 - 2

$$
I_{y, 2-2}=\frac{b}{12}\left(h^{3}-16 r^{3}-48 P_{2}^{2} r\right)
$$

te moment otpora:

$$
W_{y, 2-2}=\frac{b}{h} \frac{\left(h^{3}-16 r^{3}-48 P_{2}^{2} r\right)}{6}
$$

Uvrštavanjem dimenzija iz Tablica 1 i 2 u (1) i (2) dobivamo njihove numeričke vrijednosti:

$$
\begin{gathered}
I_{y, 2-2}=29129,17 \mathrm{~mm}^{4} \\
W_{y, 2-2}=1529,09 \mathrm{~mm}^{3}
\end{gathered}
$$

U Tablici 4 prikazan je postupak izračuna deformacija u presjecima 1 - 1 i 2 - 2 pri proizvoljno odabranoj sili $F=1,25 k N$ za eksperimentalno dobiveni modul elastičnosti $E=66,86 \mathrm{GPa}$. Iz geometrije opterećenja sa Slike 2 izračunat je konstantan moment $M_{\max }$ u području čistog savijanja te uz pomoć izvedenih momenata površine drugog reda $I_{y}$ određena deformacija u presjecima $1-1$ i 2 - 2. Također, prikazana je prosječna deformacija duž zone djelovanja čistog savijanja.

Tablica 4. Prosječna deformacija duž područja na kojem djeluje čisto savijanje

\begin{tabular}{|c|c|c|c|c|c|c|}
\hline Presjek & $\begin{array}{c}F_{\max } \\
(\mathrm{kN})\end{array}$ & $\begin{array}{c}M_{\max } \\
(\mathrm{kNm})\end{array}$ & $\begin{array}{c}I_{y} \\
\left(\mathrm{~mm}^{4}\right)\end{array}$ & $\begin{array}{c} \pm \sigma_{\max } \\
(\mathrm{MPa})\end{array}$ & $\begin{array}{c} \pm \varepsilon_{\max } \\
(\mathrm{m} / \mathrm{m})\end{array}$ & $\begin{array}{c}\text { Prosječna } \\
\text { deformacija } \pm \varepsilon\end{array}$ \\
\cline { 1 - 4 } $1-1$ & \multirow{2}{*}{1,25} & 0,0825 & 58169,54 & 27,02 & 0,00040 & \multirow{2}{*}{$0,61 * 10^{-3}$} \\
\cline { 1 - 3 } & & 29129,17 & 53,95 & 0,00081 & \\
\hline $2-2$ & & &
\end{tabular}




\section{Eksperimentalno rješenje}

Problem heterogenih nosača analiziran je eksperimentalnim putem laboratorijskim ispitivanjem metodom tenzometrije. Ispitivanje je provedeno na 5 različitih vrsta uzoraka, HMD B2, HMD B3, LMD B2, LMD B3 i na kontrolnim FM B2 uzorcima. Za svaku vrstu uzorka provedena su tri ispitivanja. Uzorci su opterećeni na način prikazan na Slici 4, hidrauličnom prešom proizvođača Controls. Opterećenje je nanošeno kontrolom sile, brzinom od 10 N/s. Pri pokusu su korišteni tenzometri 1 - LY41 - 6/120. U oznaci tenzometra, LY41 predstavlja tenzometar s dva terminala za spajanje, 6 duljinu mjernog polja u mm, a 120 električni otpor tenzometra u $\Omega$ [4]. Za ovaj model tenzometra osjetljivost mjerne trake iznosi $\mathrm{k}=$ 2,05. Prije ispitivanja uzorci su očišćeni medicinskim alkoholom, a zatim su na njih jednokomponentnim ljepilom pričvršćeni tenzometri na prije označene pozicije. Na uzorak FM B2 pričvršćena su dva tenzometra u sredini raspona nosača, jedan s donje, a drugi s gornje strane. Na ostale uzorke postavljeno je 6 tenzometara u području djelovanja čistog savijanja, tri s gornje i tri s donje strane, kao što je prikazano na Slici 6. Na uzorcima HMD B2 i LMD B2 srednji tenzometari su postavljeni iznad i ispod presjeka čije je oslabljenje iznad uzdužne osi nosača, a lijevi i desni tenzometri postavljeni su u presjeke čije je oslabljenje ispod uzdužne osi nosača. Na uzorku HMD B3 srednji tenzometari postavljeni su ispod i iznad jačeg presjeka s jednim oslabljenjem (presjek 1 - 1), a lijevi i desni tenzometri u slabijem presjeku s dva oslabljenja (presjek 2 - 2). Na uzorku LMD B3, tenzometri su postavljeni suprotno, tj. srednji tenzometari su u slabijem presjeku (2 - 2), a lijevi i desni tenzometri su u jačim presjecima (1 - 1). Tenzometri su postavljeni u smjeru elastične linije nosača i povezani u Wheatstoneov mjerni most u modulu četvrtinskog mosta. Mjerenje je obavljeno pomoću računalnog programa Signal Express.
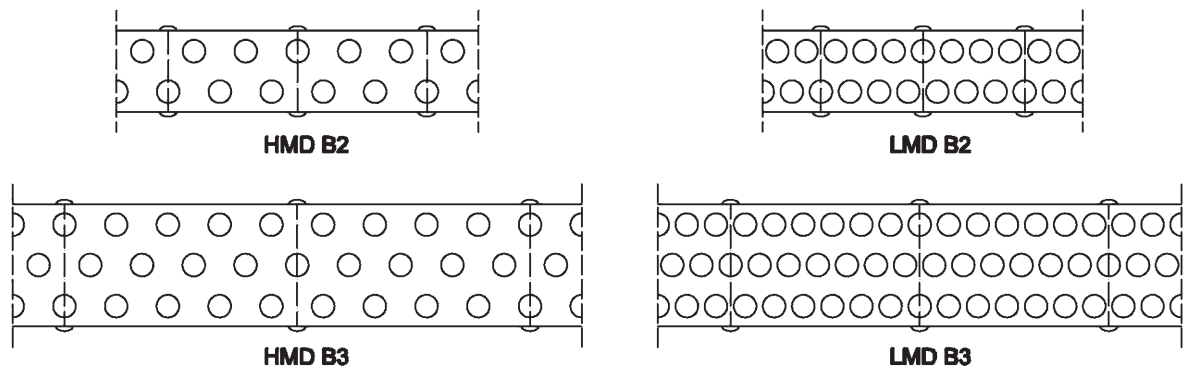

Slika 6. Položaji tenzometara 
U Tablici 5 dane su vrijednosti izmjerenih deformacija na pojedinim tenzometrima pri opterećujućim silama F. Oznake u ovoj tablici odnose se na položaj tenzometara, pri čemu G.L. označava poziciju gore lijevo, G.S. gore sredina, G.D. gore desno, D.L. dolje lijevo, D.S. dolje sredina i D.D. dolje desno.

Prilikom analize deformacija nosača FM B2 izračunat je Youngov modul elastičnosti koji iznosi $\mathrm{E}=66,86 \mathrm{GPa}$. Prilikom nanošenje sile od $F=1,75 \mathrm{kN}$ na tri različita uzorka FM B2 izmjerene su deformacije date u Tablici 5. Za istu vrijednost sile izračunat je moment savijanja i odgovarajuće maksimalno naprezanje. Za izračun modula elastičnosti korišten je omjer proračunatog maksimalnog naprezanja i prosječnih maksimalnih deformacija za sva tri mjerenja. Taj modul elastičnosti korišten je prilikom analitičkog računa i analize metodom konačnih elemenata. Budući da se ispitivanja provode u linearno elastičnoj zoni, za dobiveni modul elastičnosti i geometrijske karakteristike pojedinih nosača, proračunata je maksimalna sila kojom se pojedini uzorci mogu opteretiti. Iako je laboratorijskom pogreškom treći uzorak HMD B2 plastično deformiran, što je i vidljivo po veličini sile u Tablici 5 za taj uzorak, u analizu su uzete samo deformacije iz linearno elastične zone.

Tablica 5. Deformacije izmjerene na uzorcima metodom tenzometrije

\begin{tabular}{|c|c|c|c|c|c|c|c|c|}
\hline \multirow[b]{2}{*}{ Uzorak } & \multirow[b]{2}{*}{$\begin{array}{l}\text { Redni br. } \\
\text { testiranja }\end{array}$} & \multirow[b]{2}{*}{$\begin{array}{l}\text { Sila F } \\
(\mathrm{kN})\end{array}$} & \multicolumn{6}{|c|}{ Maksimalne apsolutne deformacije } \\
\hline & & & $\begin{array}{c}\text { G.L. } \\
(-) \\
* 10^{-3}\end{array}$ & $\begin{array}{c}\text { G.S. } \\
(-) \\
* 10^{-3}\end{array}$ & $\begin{array}{c}\text { G.D. } \\
(-) \\
* 10^{-3}\end{array}$ & $\begin{array}{l}\text { D.L. } \\
(+) \\
* 10^{-3}\end{array}$ & $\begin{array}{c}\text { D.S. } \\
(+) \\
* 10^{-3}\end{array}$ & $\begin{array}{c}\text { D.D. } \\
(+) \\
* 10^{-3}\end{array}$ \\
\hline \multirow{3}{*}{ FM B2 } & 1 & 1,75 & / & / & 0,91 & 0,93 & / & / \\
\hline & 2 & 1,75 & / & / & 0,80 & 0,79 & / & / \\
\hline & 3 & 1,75 & / & / & 0,93 & 0,96 & / & / \\
\hline \multirow{3}{*}{$\begin{array}{l}\text { HMD } \\
\text { B2 }\end{array}$} & 1 & 1,41 & 0,95 & 1,23 & 0,93 & 1,23 & 0,97 & 1,26 \\
\hline & 2 & 1,42 & 1,02 & 1,29 & 1,00 & 1,33 & 1,03 & 1,32 \\
\hline & 3 & 2,24 & 0,94 & 0,77 & 0,78 & 1,01 & 0,79 & 1,01 \\
\hline \multirow{3}{*}{ LMD B2 } & 1 & 1,25 & 1,30 & 1,55 & 1,35 & 1,59 & 1,36 & 1,63 \\
\hline & 2 & 1,26 & 1,39 & 1,70 & 1,44 & 1,74 & 1,49 & 1,82 \\
\hline & 3 & 1,27 & 1,39 & 1,68 & 1,47 & 1,72 & 1,47 & 1,83 \\
\hline \multirow{3}{*}{$\begin{array}{l}\text { HMD } \\
\text { B3 }\end{array}$} & 1 & 2,005 & 0,54 & 0,75 & 0,55 & 0,58 & 0,75 & 0,57 \\
\hline & 2 & 2,01 & 0,48 & 0,66 & 0,49 & 0,47 & 0,64 & 0,48 \\
\hline & 3 & 2,01 & 0,54 & 0,75 & 0,55 & 0,54 & 0,75 & 0,57 \\
\hline \multirow{3}{*}{ LMD B3 } & 1 & 1,255 & 0,80 & 0,70 & 0,82 & 0,81 & 0,70 & 0,81 \\
\hline & 2 & 1,26 & 0,79 & 0,71 & 0,84 & 0,82 & 0,71 & 0,85 \\
\hline & 3 & 1,26 & 0,74 & 0,66 & 0,77 & 0,79 & 0,68 & 0,81 \\
\hline
\end{tabular}


Prilikom razmatranja rezultata uočeno je kako je kod uzoraka HMD B3 deformacija izmjerena na srednjim tenzometrima veća od onih izmjerenih sa strane, što je suprotno našem intuitivnom zaključku. Naime, srednji presjek je presjek $1-1$, odnosno jači presjek, te ima veći moment površine drugog reda od onih sa strane. Isto se događa kod uzoraka LMD B3, gdje jači presjeci koji se nalaze sa strane bilježe veće deformacije od slabijeg presjeka koji je u sredini. Samom analizom eksperimentalnih rezultata nije moguće dati odgovor zašto je tome tako.

Radi lakše daljnje analize očitane su vrijednosti deformiranja pri sili opterećenja $F=1,25 \mathrm{kN}$ za sve nosače. Prosjek tih vrijednosti duž nosača dan je u Tablici 6.

Tablica 6. Prosječne izmjerene deformacije uzoraka HMD B3 i LMD B3 pri opterećenju $F=1,25 \mathrm{kN}$

\begin{tabular}{|c|c|c|}
\hline \multirow[b]{2}{*}{ Uzorak } & \multicolumn{2}{|c|}{ Deformacije } \\
\hline & $\begin{array}{c}\text { Vlačne } \\
* 10^{-3}\end{array}$ & $\begin{array}{l}\text { Tlačne } \\
* 10^{-3}\end{array}$ \\
\hline FM B2 & 0,90 & 0,88 \\
\hline HMD B2 & 1,10 & 0,99 \\
\hline LMD B2 & 1,63 & 1,47 \\
\hline HMD B3 & 0,60 & 0,59 \\
\hline LMD B3 & 0,78 & 0,76 \\
\hline
\end{tabular}

\section{Numeričko rješenje}

Treći način na koji je ovaj problem analiziran je pomoću metode konačnih elemenata. Geometrija uzoraka modelirana je u računalnom programu Gmsh 3.0.5 te je u istom programu generirana mreža konačnih elemenata. Za LMD uzorke je uzet veći broj konačnih elemenata kako bi se bolje opisala koncentracija naprezanja oko oslabljenja nosača. U Tablici 7 prikazan je odabrani broj elemenata za svaki uzorak. Kako bi se optimizirao broj jednadžbi koji je potrebno izračunati, sve mreže elemenata postavljene su na način da je mreža gušća uz vanjske rubove, tj. na mjestima gdje su tenzometri, a rjeđa izvan područja djelovanja čistog savijanja. Modeli nosača koji određuju rubne uvijete i mreže konačnih elemenata uneseni su u računalni program FEAP [5] unutar kojeg je odrađena analiza metodom konačnih elemenata. Uzorci su diskretizirani trokutnim, tročvornim konačnim elementima $s$ dva stupnja slobode po čvoru (pomaci $u$ horizontalnom i vertikalnom smjeru). Za numerički proračun uzet je modul elastičnosti određen pomoću kontrolnih uzoraka i Poissonov koeficijent 
$v=0.3$. $\mathrm{U}$ Tablici 8 prikazane su vrijednosti deformacija dobivene metodom konačnih elemenata za vrijednosti sila $1,40 \mathrm{kN}, 1,25 \mathrm{kN}, 2,00 \mathrm{kN}$ i 2,25 kN redom za uzorke HMD B2, LMD B2, HMD B3 i LMD B3.

Tablica 7. Broj elemenata u mreži za pojedinu vrstu uzoraka

\begin{tabular}{|c|c|}
\hline Uzorak & $\begin{array}{c}\text { Broj } \\
\text { elemenata }\end{array}$ \\
\hline HMD B2 & 8814 \\
\hline LMD B2 & 10388 \\
\hline HMD B3 & 13058 \\
\hline LMD B3 & 16525 \\
\hline
\end{tabular}

Tablica 8. Vlačne i tlačne deformacije uzoraka dobivene metodom konačnih elemenata

\begin{tabular}{|c|c|c|c|c|c|c|c|}
\hline & & \multicolumn{5}{|c|}{ Deformacije pri maksimalnim silama } \\
\cline { 3 - 8 } Uzorak & Sila opterećenja & $\begin{array}{c}\text { G.L. } \\
(-)\end{array}$ & $\begin{array}{c}\text { G.S. } \\
(-)\end{array}$ & $\begin{array}{c}\text { G.D. } \\
(-)\end{array}$ & $\begin{array}{c}\text { D.L. } \\
(+)\end{array}$ & $\begin{array}{c}\text { D.S. } \\
(+)\end{array}$ & $\begin{array}{c}\text { D.D. } \\
(+)\end{array}$ \\
& $F$ & $* 10^{-3}$ & $* 10^{-3}$ & $* 10^{-3}$ & $* 10^{-3}$ & $* 10^{-3}$ & $* 10^{-3}$ \\
\hline HMD B2 & 1,40 & 1,11 & 1,57 & 1,11 & 1,53 & 1,11 & 1,53 \\
\hline LMD B2 & 1,25 & 1,22 & 1,61 & 1,22 & 1,61 & 1,22 & 1,60 \\
\hline HMD B3 & 2,00 & 0,70 & 1,05 & 0,70 & 0,70 & 1,05 & 0,70 \\
\hline LMD B3 & 1,25 & 0,75 & 0,55 & 0,77 & 0,75 & 0,55 & 0,77 \\
\hline
\end{tabular}

I ovdje je vidljiva pojava inverzije očekivanog odnosa vrijednosti deformacija između jačeg presjeka $1-1$ i slabijeg presjeka 2 - 2. Stoga možemo isključiti pretpostavku o pogrešci pri laboratorijskom mjerenju. Na Slici 7 prikazana je vizualizacija, izrađena pomoću računalnog programa Paraview 5.5.1 na temelju podataka dobivenih metodom konačnih elemenata za uzorke HMD B2 i HMD B3. Vidljiva je pojava tlačnih, odnosno vlačnih lukova kojima su ishodišta u vrhovima kružnica oslabljenja, a tjemena na rubu nosača (Slika 8). Također je moguće uočiti da se iznad svake kružnice oslabljenja pojavljuje područje smanjenih deformacija. Možemo zaključiti kako unutar strukture nosača dolazi do preraspodjele naprezanja, a samim time i deformacija te se najveće deformacije pomiču od ruba nosača prema rubu kružnice oslabljenja. Ovaj mehanizam preraspodijele naprezanja nam daje odgovor zašto su deformacije veće na rubovima presjeka koje smo definirali kao jače presjeke (presjek 1 - 1). Isti mehanizam se pojavljuje i na nosačima LMD strukture.

U Tablici 9 prikazane su prosječne vrijednosti deformacija duž nosača pri sili $F=1,25 \mathrm{kN}$. 

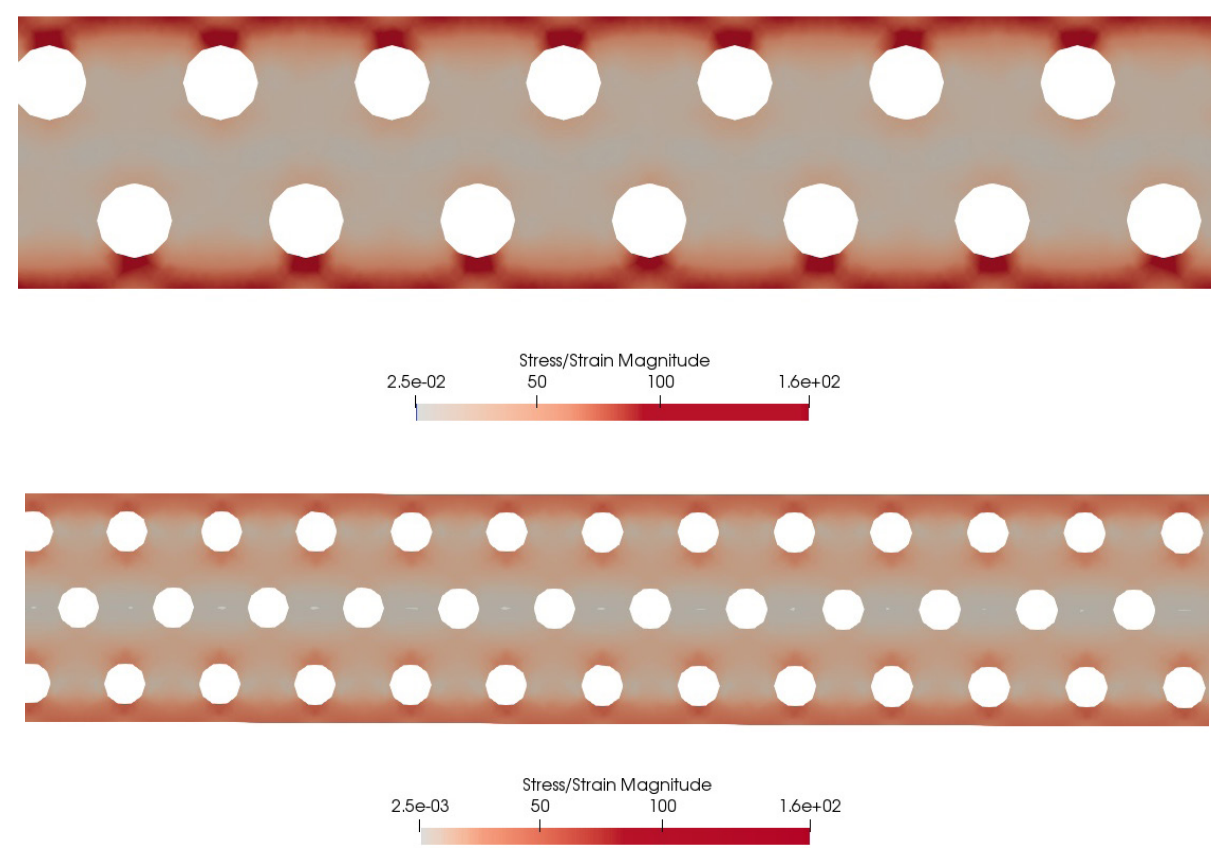

Slika 7. Deformacije dobivene metodom konačnih elemenata za uzorke HMD B2 (gore) i HMD B3 (dolje)

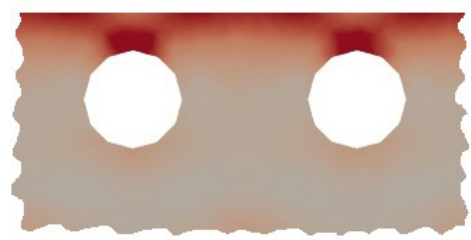

Slika 8. Pojava tlačnih lukova između dva oslabljenja na uzorku HMD B2

Tablica 9. Vlačne i tlačne deformacije pri sili $F=1,25 \mathrm{kN}$ dobivene metodom konačnih elemenata

\begin{tabular}{|c|c|c|}
\hline \multirow{2}{*}{ Uzorak } & \multicolumn{2}{|c|}{ Maksimalne deformacije } \\
\cline { 2 - 3 } & $\begin{array}{c}\text { Vlačne } \\
* 10^{-3}\end{array}$ & $\begin{array}{c}\text { Tlačne } \\
* 10^{-3}\end{array}$ \\
\hline HMD B2 & 1,23 & 1,12 \\
\hline LMD B2 & 1,48 & 1,35 \\
\hline HMD B3 & 0,51 & 0,51 \\
\hline LMD B3 & 0,68 & 0,68 \\
\hline
\end{tabular}




\section{Usporedba dobivenih rezultata}

Na Slici 9 prikazan je dijagram s vrijednostima eksperimentalno izmjerenih i numerički dobivenih vlačnih i tlačnih deformacija za sve četiri vrste uzoraka te analitički dobivenih deformacija za uzorke HMD B3 i LMD B3. Vidljivo je kako su analitički dobivene deformacije manje od izmjerenih, no deformacije dobivene metodom konačnih elemenata manje su od analitički dobivenih za uzorke HMD B3, a veće od analitički dobivenih za uzorke LMD B3. Također je vidljivo kako su deformacije dobivene metodom konačnih elemenata manje od onih izmjerenih za sve uzorke osim HMD B3.

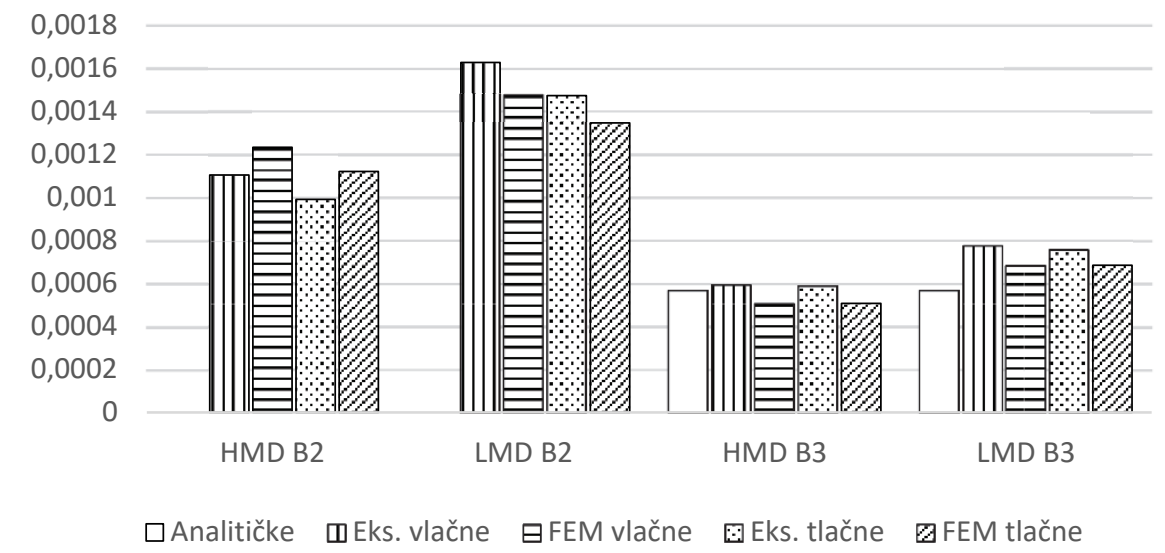

Slika 9. Odnos dobivenih deformacija pri sili $F=1,25 \mathrm{kN}$ za pojedine uzorke

U Tablici 10 prikazan je odnos veličina vlačnih i tlačnih deformacija pri sili $F=1,25 \mathrm{kN}$ dobivenih analizom konačnih elemenata i laboratorijskim mjerenjima. Vidljivo je kako razlika u rezultatima nije veća od $15 \%$ te nam je ta razlika prihvatljiva.

U Tablici 11 prikazan je odnos analitički dobivenih deformacija i rezultata laboratorijskih mjerenja za nosače HMD B3 i LMD B3 pri sili $F=1,25 \mathrm{kN}$. Rezultati za uzorak HMD B3 su približno jednaki, no kod onih za uzorak LMD B3 odstupanja su značajna. To možemo pripisati ortotropnosti uzoraka. Naime, uzorci strukture HMD i LMD nemaju ista svojstva u smjeru paralelnom osi nosača i okomito na njega. Kao što je prije navedeno, horizontalna udaljenost oslabljenja $\mathrm{P}_{1}$ je veća za strukturu HMD i iznosi $16 \mathrm{~mm}$, dok za strukturu LMD iznosi $9 \mathrm{~mm}$, a vertikalna udaljenost oslabljenja $\mathrm{P}_{2}$ je jednaka i iznosi $12,7 \mathrm{~mm}$. To znači da je struktura HMD kruća u smjeru paralelnom osi nosača nego okomito na nju. Suprotno vrijedi za strukturu LMD.

U Tablici 12 prikazan je odnos tlačnih i vlačnih deformacija pri sili $F=1,25 \mathrm{kN}$ dobivenih eksperimentalnim putem i metodom konačnih 
elemenata. Kod gotovo svih uzoraka, dobivene vlačne deformacije veće su od tlačnih. Vidljivo je kako je odnos vlačnih i tlačnih deformacija analogan za rezultate dobivene mjerenjima i one dobivene metodom konačnih elemenata, no primjenom metode konačnih elemenata njihova je razlika manja. Kod uzoraka veličine B3 tlačne i vlačne deformacije su gotovo iste apsolutne vrijednosti, a male razlike pri eksperimentalno dobivenim mjerenjima možemo objasniti šumom signala tokom mjerenja. Rezultati dobiveni metodom konačnih elemenata daju deformacije jednake apsolutne vrijednosti za nosač HMD B3, a možemo pretpostaviti da bi uzimanjem većeg broja elemenata bile jednake i za nosač LMD B3. Kod nosača dimenzija B2 razlika između tlačnih i vlačnih deformacija značajnija je nego kod uzoraka B3. Odgovor na pitanje zašto je tome tako nalazi se u distribuciji masa u pojedinim poprečnim presjecima. Naime, kako je i kazano u definiciji heterogenih nosača, nosači dimenzija B3 simetrični su u odnosu na os nosača, koja im je ujedno i neutralna os. Pošto je neutralna os nosača B2 krivulja, odnosno nosač nije simetričan s obzirom na neutralnu os, dodatna naprezanja unutar nosača utječu na razliku između tlačnih i vlačnih naprezanja, odnosno u gornjem pojasu nosača jedan se tenzometar nalazi direktno iznad oslabljenja, a u donjem pojasu su dva tenzometra direktno iznad oslabljenja. Stoga su i prosječne deformacije u donjem pojasu veće od onih u gornjem.

Tablica 10. Odnos deformacija dobivenih metodom konačnih elemenata $i$ eksperimentalnim mjerenjima

\begin{tabular}{|c|c|c|}
\hline \multirow{2}{*}{ Uzorak } & \multicolumn{2}{|c|}{ FEM/eksperimentalne } \\
& Vlačne & Tlačne \\
\cline { 2 - 3 } & \%) \\
\hline HMD B2 & 111,74 & 113,09 \\
\hline LMD B2 & 90,75 & 91,36 \\
\hline HMD B3 & 85,26 & 85,93 \\
\hline LMD B3 & 88,30 & 90,35 \\
\hline
\end{tabular}

Tablica 11. Odnos analitički i eksperimentalno dobivenih deformacija

\begin{tabular}{|c|c|c|}
\hline \multirow{2}{*}{ Uzorak } & \multicolumn{2}{|c|}{ analitičke/eksperimentalne } \\
& Vlačne & Tlačne \\
\cline { 2 - 3 } & 95,81 & 96,56 \\
\hline HMD B3 & 73,52 & 75,26 \\
\hline LMD B3 &
\end{tabular}


Tablica 12. Odnos tlačnih i vlačnih deformacija dobivenih eksperimentalnim mjerenjima i metodom konačnih elemenata

\begin{tabular}{|c|c|c|}
\hline \multirow{2}{*}{ Uzorak } & \multicolumn{2}{|c|}{ tlačne/vlačne (\%) } \\
\cline { 2 - 3 } & Eksperimentalne & FEM \\
\hline HMD B2 & 89,74 & 90,83 \\
\hline LMD B2 & 90,53 & 91,13 \\
\hline HMD B3 & 99,22 & 100,00 \\
\hline LMD B3 & 97,69 & 99,96 \\
\hline
\end{tabular}

\section{Zaključak}

Nosači heterogene ortotropne strukture nazvane HMD i LMD u dimenzijama B2 i B3 izrađeni po uzoru na nosače analizirane $u$ istraživanju A.J. Beveridgea, M.A. Wheela i D.H. Nasha [2] analizirani su analitičkim putem grednom teorijom, eksperimentalnim putem metodom tenzometrije i numeričkim putem metodom konačnih elemenata. Gredna teorija dala je približno dobro rješenje pri analizi nosača HMD B3, no kod nosača LMD B3 greška je bila vrlo velika u odnosu na laboratorijska mjerenja koja su uzeta kao referentna vrijednost. To je pripisano ortotropnosti nosača, koja čini grednu teoriju neupotrebljivom za analizu ovakvih problema. Također, nosače veličine B2 zbog geometrije nije bilo moguće analizirati ovim putem. Analiza metodom konačnih elemenata dala je manje točne rezultate u odnosu na grednu teoriju za HMD strukturu, ali izrazito točnije za LMD strukturu. $\mathrm{K}$ tome, pomoću nje su uspješno analizirani nosači veličine B2. Uočena je velika razlika između tlačnih i vlačnih deformacija kod uzoraka veličine B2 pri analizi konačnih elemenata i eksperimentalnim rezultatima koja nije objašnjena, no pretpostavka je kako se radi o utjecaju zakrivljene neutralne osi nosača. Metoda konačnih elemenata dala je odgovor na pojavu većih deformacija u presjecima s većim momentom tromosti, u odnosu na one s manjim momentom tromosti. Odgovor se nalazi u formiranju tlačnih i vlačnih lukova unutar strukture oslabljenja nosača koje raspodjeljuju naprezanja, a time i deformacije od ruba nosača te ih koncentriraju na rubove oslabljenja. Ovim radom dokazano je kako gredna teorija nije adekvatna za analizu nosača ortotropnih struktura te je za takvu analizu puno adekvatnija metoda konačnih elemenata. Također, pokazana su zanimljiva svojstva strukture koja je oslabljena na ovaj način te su otvorena pitanja o razlici apsolutnih vrijednosti tlačnih i vlačnih deformacija pri nosačima HMD B2 i LMD B2. 
Zahvala. Rad je nastao kao rezultat aktivnosti u okviru znanstvenog projekta Fixed-Pole Concept in Numerical Modelling of Cosserat Continuum (HRZZ-IP-2018-01-1732), kojega financira Hrvatska zaklada za znanost te sveučilišne potpore Sveučilišta u Rijeci Computational and Experimental Procedures for Assessment of Material Parameters in Cosserats' Continuum (uniri-tehnic-18-248 1415), a u radu je korištena laboratorijska oprema nabavljena unutar infrastrukturnog projekta Razvoj istraživačke infrastrukture na kampusu Sveučilišta u Rijeci (RC.2.2.06-0001) koji je sufinanciran iz Europskog fonda za regionalni razvoj (EFRR) i Ministarstva znanosti, obrazovanja i sporta $R H$.

\section{Literatura}

[1] R. Lakes, »Experimental Microelasticity of Two Porous Solids, « International Journal of Solids and Structures, svez. 22, br. 1, pp. 55-63, 1986.

[2] A.J. Beveridge; M.A. Wheel; D.H. Nash;, »The Micropolar Elastic Behaviour of Model Macroscopically Heterogeneous Materials, « International Journal of Solids and Structures, pp. 246-255, 2013..

[3] V. Šimić, Otpornost materijala I, Zagreb: Školska knjiga, 1992.

[4] National Instruments, »Measuring Strain with Strain Gages, « National Instruments, 2020..

[5] R. Taylor, »FEAP - Finite Element Analysis Program,« 2014.. [Mrežno]. Available: http://www.ce.berkeley/feap. [Pokušaj pristupa 2021]. 
